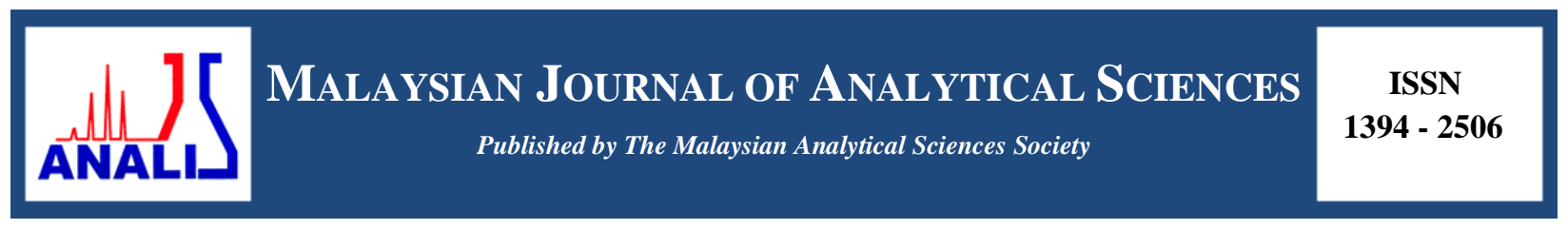

\title{
CHEMICAL CONSTITUENTS FROM THE LIANAS OF Gnetum cuspidatum Blume
}

\author{
(Sebatian Kimia dari Lianas Gnetum cuspidatum Blume) \\ Nik Fatini Nik Azmin ${ }^{1}$, Norizan Ahmat ${ }^{1,2} *$, Nik Khairunissa Nik Abdullah Zawawi ${ }^{1,2}$ \\ ${ }^{I}$ Faculty of Applied Sciences, \\ Universiti Teknologi MARA, 40450 Shah Alam, Selangor, Malaysia \\ ${ }^{2}$ Atta-ur-Rahman Institute for Natural Product Discovery, \\ Universiti Teknologi MARA, Puncak Alam Campus, 42300 Bandar Puncak Alam, Selangor, Malaysia \\ *Corresponding author: noriz118@salam.uitm.edu.my
}

Received: 24 February 2015; Accepted: 27 October 2015

\begin{abstract}
Gnetum is a genus of gymnosperms, the sole genus in the family Gnetaceae with approximately 40 species. Various species has been used for the treatment of rheumatitis, arthritis, bronchitis and asthma in folk medicines. Gnetum cuspidatum Blume is known throughout tropical Southeast Asia from Thailand, Vietnam, Cambodia, Malaysia, Sumatra, Java, and Borneo to the Maluku, Sulawesi and New Guinea. In this research work, a methanol extract of the lianas of Gnetum cuspidatum was subjected to vacuum liquid chromatography for fractionation. Later, several selective fractions had undergone the repetitive radial chromatography technique for further purification. Four known constituents categorized as stilbene type of compound have been successfully isolated and identified which include resveratrol (1), gnetucleistol C (2), gnetucleistol D (3) and gnemonol M (4). The structures and configuration of the reported compounds were elucidated on the basis of 2D-NMR correlations and comparison with the literature.
\end{abstract}

Keywords: Gnetaceae, Gnetum, Gnetum cuspidatum, stilbene

\begin{abstract}
Abstrak
Gnetum merupakan genus gymnosperms, genus tunggal dalam keluarga Gnetaceae dengan kira-kira 40 spesies. Pelbagai spesies telah digunakan untuk rawatan rheumatitis, arthritis, bronkitis dan asma dalam perubatan penduduk tempatan. Gnetum cuspidatum Blume dikenali di seluruh tropika Asia Tenggara dari Thailand, Vietnam, Kemboja, Malaysia, Sumatera, Jawa, Borneo dan ke Maluku, Sulawesi dan New Guinea. Satu ekstrak metanol daripada lianas Gnetum cuspidatum telah menggunakan vakum kromatografi cecair untuk pemisahan. Kemudian, beberapa pemisahan yang terpilih telah menjalani teknik kromatografi jejarian secara berulang kali untuk penulenan lanjut. Empat sebatian yang dikategorikan sebagai jenis stilbene telah berjaya diasingkan dan dikenalpasti iaitu resveratrol (1), gnetucleistol C (2), gnetucleistol D (3) dan gnemonol M (4). Struktur dan konfigurasi sebatian yang telah dilapor ini berdasarkan korelasi 2D-NMR dan perbandingan dengan kajian literatur.
\end{abstract}

Kata kunci: Gnetaceae, Gnetum, Gnetum cuspidatum, stilben

\section{Introduction}

The genus Gnetum from the family of Gnetaceae comprises approximately 40 species which were found in the tropical lowlands of the world from Northeastern South America, tropical West Africa, and South China to Southeast Asia. The plants are known to contain stilbenoids or oligostilbene and have been ethnobotanically used as folk medicine as well as food [1]. Previously, many studies have been done on several species of Gnetum and 
revealed various stilbenes and oligostilbenes type of compounds as its major chemical constituents. Interestingly, some of the isolated compounds display multiple bioactivities such as antioxidant, anti-inflammatory and antitumor [2].

In our search for structurally and biological interesting compounds from tropical plants found in Malaysia, the lianas of Gnetum cuspidatum has been investigated. Gnetum cuspidatum Blume is known throughout tropical Southeast Asia from Thailand, Vietnam, Cambodia, Malaysia, Sumatra, Java, and Borneo to the Maluku, Sulawesi and New Guinea. Previous study revealed the isolation of isorhapontigenin from the stem [3] and two new compounds recently report by Shimokawa et al. [4] known as cuspidan A and cuspidan B from the bark of this plant.

In this study, the methanol extract of the lianas of this plant has led to the isolation of four known stilbenoid compounds, resveratrol (1) [5], gnetucleistol C (2) [6], gnetuclesitol D (3) [7] and gnemonol M (4) [8]. The structures were determined using spectroscopic techniques of 1D and 2D NMR, MS and comparison with previous reports

\section{Chemicals and raw materials}

\section{Materials and Methods}

All the chemicals used were of analytical grade and purchased from Sigma Chemical Co. (St Louis, Missouri). The lianas of Gnetum cuspidatum was collected at Taman Negara, Pahang in August 2011 and identified by Dr Shamsul, a botanist from Universiti Putra Malaysia (UPM), Serdang.

\section{Extraction and isolation of constituents from plant materials}

The lianas were air-dried, ground $(2 \mathrm{~kg})$ and macerated in methanol which then filtered and concentrated under reduced pressure to obtain crude extract $(214.8 \mathrm{~g})$. The crude extract with less tannin $(62.60 \mathrm{~g})$ then was subjected to fractionation by using vacuum liquid chromatography (VLC) with various composition of solvent system [nhexane: EtoAC (7:3, 6:4, 5:5, 3:7, 2:8, 1:9) and EtoAC: $\mathrm{MeOH}(10: 0,9: 1,8: 2)]$ to yield five major fractions. All pure compounds reported were obtained from one single fraction. Fraction $4(10.54 \mathrm{~g})$ was subjected to isolation and purification using separation technique of multiple radial chromatography and preparative thin layer chromatography (pTLC) with solvent system of chloroform: methanol (8.5:1.5), and chloroform: acetone (8:2) to yield $1(1 \mathrm{mg}), 2(3.1 \mathrm{mg}), \mathbf{3}(6.1 \mathrm{mg})$ and $\mathbf{4}(12.1 \mathrm{mg})$.

\section{Purification and structure elucidation of pure compounds}

The structure determination of the constituents isolated from the plants was done using several spectroscopic methods. The ${ }^{1} \mathrm{H}-\mathrm{NMR}$ and ${ }^{13} \mathrm{C}-\mathrm{NMR}$ were recorded in acetone-D on Bruker 300 Ultrashield NMR spectrometer measured at $300 \mathrm{MHz}$ for ${ }^{1} \mathrm{H}$ NMR and $75 \mathrm{MHz}$ for ${ }^{13} \mathrm{C}$ NMR. Chemical shifts were reported in ppm $(\delta)$ and the coupling constants are given in Hz. The mass spectra were measured on Agilent Technologies LC-MS. Melting point was measured by Fisher Johns 'micro melting point apparatus'.

For purification process to obtain a single constituent, various chromatographic techniques have been applied. Vacuum liquid chromatography (VLC) used silica gel 60, 70 - 230 mesh ASTM (Merck 1.07747), column chromatography using Si-gel Merck $60(200-400$ mesh) and TLC analysis on pre-coated Si-gel plates Si-gel Merck Kiesel gel $60 \mathrm{~F} 2540.25 \mathrm{~mm}, 20 \times 20 \mathrm{~cm}$ while glass supported silica gel $60 \mathrm{~F}_{254}$ was used for preparative thin layer chromatography.

\section{Results and Discussion}

Four known compounds, resveratrol (1), gnetucleistol C (2), gnetucleistol D (3) and gnemonol M (4) (Figure 1) were successfully isolated from the methanol extract of the lianas of G.cuspidatum. The known compounds were elucidated on the basis of NMR $\left({ }^{1} \mathrm{H}\right.$ and $\left.{ }^{13} \mathrm{C}\right)$ technique and by comparison of physical and spectroscopic data with values found in the literature. Table 1 displayed all ${ }^{13} \mathrm{C}$ NMR data of the compounds isolated. Resveratrol (1), a naturally occurring stilbene in Gnetum plants was obtained as white amorphous powder. ${ }^{1} \mathrm{H}$ NMR $(300 \mathrm{MHz}$, in Acetone-d6) revealed two sets of ortho-coupled aromatic protons on a $p$-substituted phenyl moieties (ring B) at $\delta_{\mathrm{H}} 7.40(2 \mathrm{H}, \mathrm{d}, J=8.7 \mathrm{~Hz}, \mathrm{H}-2,6)$ and $\delta_{\mathrm{H}} 6.82(2 \mathrm{H}, \mathrm{d}, J=8.4 \mathrm{~Hz}, \mathrm{H}-3,5)$. The spectrum also displayed one set of 
meta-coupled aromatic proton $\delta_{\mathrm{H}} 6.53(2 \mathrm{H}, \mathrm{d}, J=2.4 \mathrm{~Hz}, \mathrm{H}-10,14)$ and one meta-triplet at $\delta_{\mathrm{H}} 6.26(1 \mathrm{H}, \mathrm{t}, J=2.1$, $2.4 \mathrm{~Hz}, \mathrm{H}-12)$ on a 1,3,5-trisubstituted benzene ring (ring A). A pair of trans-coupled olefinic proton at $\delta_{\mathrm{H}} 6.99(1 \mathrm{H}$, d, $J=16.8 \mathrm{~Hz}, \mathrm{H}-7) / 6.90(1 \mathrm{H}, \mathrm{d}, J=16.2 \mathrm{~Hz}, \mathrm{H}-8)$ were also observed.

Gnetucleistol C (2) was obtained as an amorphous white powder. The ${ }^{1} \mathrm{H}$ NMR spectrum in acetone-d6 exhibited signals attributable to a methoxy proton at $\delta_{\mathrm{H}} 3.95(3 \mathrm{H}, \mathrm{s})$, an $\mathrm{AB}_{2}$ system at $\delta_{\mathrm{H}} 6.39(1 \mathrm{H}, \mathrm{t}, J=2.1 \mathrm{~Hz}, \mathrm{H}-4), \delta_{\mathrm{H}} 6.91$ $(2 \mathrm{H}, \mathrm{d}, J=2.1 \mathrm{~Hz}, \mathrm{H}-2,6)$, an ABX system at $\delta_{\mathrm{H}} 6.75(1 \mathrm{H}, \mathrm{d}, J=8.1 \mathrm{~Hz}, \mathrm{H}-11), \delta_{\mathrm{H}} 7.12(1 \mathrm{H}, \mathrm{dd}, J=8.4,0.9 \mathrm{~Hz}, \mathrm{H}-$ $13), \delta_{\mathrm{H}} 7.23(1 \mathrm{H}, \mathrm{t}, J=8.4,8.1 \mathrm{~Hz}, \mathrm{H}-12)$, and a doublet at $\delta_{\mathrm{H}} 7.14(1 \mathrm{H}, \mathrm{d}, J=0.9 \mathrm{~Hz}, \mathrm{H}-8)$, which display a longrange correlations with the signal of $\mathrm{C}-1$ and C-9. Based on comparison with the ${ }^{1} \mathrm{H}$ and ${ }^{13} \mathrm{C}$ NMR data of gnetifolin A [5], compound 2 was deduced to have a benzofuran skeleton and was categorized under arylbenzofuran monomer type of stilbene.

Gnetuclesitol D (3), also known as 2-methoxyresveratrol was obtained as white amorphous powder. ${ }^{1} \mathrm{H}$ NMR (300 $\mathrm{MHz}$, in Acetone-d6) displayed a single peak at $\delta_{\mathrm{H}} 3.89(3 \mathrm{H}, \mathrm{s})$, showing the existence of an additional substituent which was a methoxy group on carbon 2 of ring B. Signals of one set of meta-coupled aromatic protons at $\delta_{\mathrm{H}} 6.53$ $(2 \mathrm{H}, \mathrm{d}, J=2.4 \mathrm{~Hz}, \mathrm{H}-10,14)$ and one meta-triplet at $\delta_{\mathrm{H}} 6.27(1 \mathrm{H}, \mathrm{d}, J=2.1 \mathrm{~Hz}, \mathrm{H}-12)$ were revealed on ring A. The spectrum also showed an $\mathrm{ABX}$ system on a 1,2,4-trisubtituted benzene ring (ring B) at $\delta_{\mathrm{H}} 6.79(1 \mathrm{H}, \mathrm{d}, J=8.1 \mathrm{~Hz}, \mathrm{H}-$ $6), \delta_{\mathrm{H}}(6.99, \mathrm{dd}, J=2.1,8.4 \mathrm{~Hz}, \mathrm{H}-5)$ and $\delta_{\mathrm{H}} 7.21(1 \mathrm{H}, \mathrm{d}, J=2.1, \mathrm{H}-3)$. A pair of trans-coupled olefinic proton at $\delta_{\mathrm{H}} 7.05(1 \mathrm{H}, \mathrm{d}, J=16.5 \mathrm{~Hz}, \mathrm{H}-7) / 6.89(1 \mathrm{H}, \mathrm{d}, J=16.2 \mathrm{~Hz}, \mathrm{H}-8)$ was also shown.

Gnemonol M (4) was obtained as a colorless amorphous powder. The ${ }^{1} \mathrm{H}$ NMR spectrum showed the presence of six sets of $\mathrm{H}$-atoms in $\mathrm{ABX}$ systems on two units of $1,3,4$-trisubstituted benzene rings at $\delta_{\mathrm{H}} 6.96(1 \mathrm{H}, \mathrm{d}, \mathrm{J}=1.8 \mathrm{~Hz}, \mathrm{H}$ 2a)/6.72 (1H, d, J = 8.1 Hz, H-5a)/6.65 (1H, dd, J = 1.8, 8.1 Hz, H-6a); $\delta_{\mathrm{H}} 6.61(1 \mathrm{H}, \mathrm{d}, \mathrm{J}=2.1 \mathrm{~Hz}, \mathrm{H}-2 \mathrm{~b}) / 6.57(1 \mathrm{H}$, $\mathrm{d}, \mathrm{J}=8.1 \mathrm{~Hz}, \mathrm{H}-5 \mathrm{~b}) / 6.39(1 \mathrm{H}, \mathrm{dd}, \mathrm{J}=2.1 \mathrm{~Hz}, 8.1, \mathrm{H}-6 \mathrm{~b})$. The spectrum also showed four sets of meta-coupled $\mathrm{H}-$ atoms in $\mathrm{AB}$ systems on two units of tetra-substituted benzene rings at $\delta_{\mathrm{H}} 6.54(1 \mathrm{H}, \mathrm{d}, \mathrm{J}=2.7 \mathrm{~Hz}, \mathrm{H}-14 \mathrm{a}) / 6.06(1 \mathrm{H}$, $\mathrm{d}, \mathrm{J}=1.8 \mathrm{~Hz}, \mathrm{H}-12 \mathrm{a}) ; \delta_{\mathrm{H}} 6.44(1 \mathrm{H}, \mathrm{d}, \mathrm{J}=2.4 \mathrm{~Hz}, \mathrm{H}-14 \mathrm{~b}) / 6.16(1 \mathrm{H}, \mathrm{d}, \mathrm{J}=2.4 \mathrm{~Hz}, \mathrm{H}-12 \mathrm{~b})$. Four benzylic methine singlets at $\delta_{\mathrm{H}} 4.20(\mathrm{H}-7 \mathrm{a}) ; 3.69(\mathrm{H}-8 \mathrm{a}) ; 4.13(\mathrm{H}-8 \mathrm{~b}) ; 3.77(\mathrm{H}-7 \mathrm{~b})$, two signals for methoxyl groups at $\delta_{\mathrm{H}} 3.79(\mathrm{OMe}-$ $3 \mathrm{a}) ; 3.64(\mathrm{OMe}-3 \mathrm{~b})$, and phenolic proton at $\delta_{\mathrm{H}} 8.02$ was also observed in the spectrum.

Table 1. Spectroscopic data $\left({ }^{13} \mathrm{C}\right.$ NMR $)$ for compound $1-4$

\begin{tabular}{ccccc}
\hline \multirow{2}{*}{ No. of carbon } & \multicolumn{4}{c}{ Compounds } \\
\cline { 2 - 5 } & $\mathbf{1}$ & $\mathbf{2}$ & $\mathbf{3}$ & $\mathbf{4}$ \\
& $\boldsymbol{\delta}_{\mathbf{C}}$ & $\boldsymbol{\delta}_{\mathbf{C}}$ & $\boldsymbol{\delta}_{\mathbf{C}}$ & $\boldsymbol{\delta}_{\mathbf{C}}$ \\
\hline 1 & 128.9 & 133.9 & 129.5 & 139.0 \\
2 & 127.8 & 105.0 & 147.8 & 113.0 \\
3 & 115.5 & 160.9 & 109.3 & 147.6 \\
4 & 157.4 & 105.0 & 146.7 & 145.5 \\
5 & 115.5 & 160.9 & 120.3 & 115.2 \\
6 & 127.8 & 105.0 & 115.1 & 121.4 \\
7 & 128.2 & 159.8 & 128.5 & 48.5 \\
8 & 125.9 & 100.5 & 126.2 & 58.7 \\
9 & 139.9 & 121.1 & 139.9 & 148.0 \\
10 & 104.7 & 155.4 & 104.7 & 127.8 \\
11 & 158.8 & 105.9 & 158.7 & 158.6 \\
12 & 101.8 & 127.1 & 101.9 & 102.8 \\
13 & 158.8 & 105.5 & 158.7 & 158.6 \\
14 & 104.7 & 157.6 & 104.7 & 104.2 \\
\hline
\end{tabular}


Nik Fatini et al: CHEMICAL CONSTITUENTS FROM THE LIANAS OF Gnetum cuspidatum Blume

Table 1 (cont'd). Spectroscopic data $\left({ }^{13} \mathrm{C}\right.$ NMR) for compound $1-4$

\begin{tabular}{|c|c|c|c|c|}
\hline \multirow{3}{*}{ No. of carbon } & \multicolumn{4}{|c|}{ Compounds } \\
\hline & 1 & 2 & 3 & 4 \\
\hline & $\boldsymbol{\delta}_{\mathrm{C}}$ & $\boldsymbol{\delta}_{\mathbf{C}}$ & $\delta_{\mathrm{C}}$ & $\boldsymbol{\delta}_{\mathrm{C}}$ \\
\hline $\mathrm{OCH}_{3}$ & & 56.9 & 55.4 & \\
\hline $\mathrm{OCH}_{3}(3 \mathrm{a})$ & & & & 57.3 \\
\hline $\mathrm{OCH}_{3}(3 b)$ & & & & 56.9 \\
\hline $1 b$ & & & & 136.2 \\
\hline $2 b$ & & & & 112.3 \\
\hline $3 b$ & & & & 147.6 \\
\hline $4 b$ & & & & 145.5 \\
\hline $5 b$ & & & & 115.2 \\
\hline $6 \mathrm{~b}$ & & & & 120.9 \\
\hline $7 b$ & & & & 52.0 \\
\hline $8 b$ & & & & 51.2 \\
\hline $9 b$ & & & & 147.2 \\
\hline $10 \mathrm{~b}$ & & & & 113.4 \\
\hline $11 b$ & & & & 157.9 \\
\hline $12 \mathrm{~b}$ & & & & 102.8 \\
\hline $13 b$ & & & & 157.2 \\
\hline $14 \mathrm{~b}$ & & & & 105.7 \\
\hline
\end{tabular}

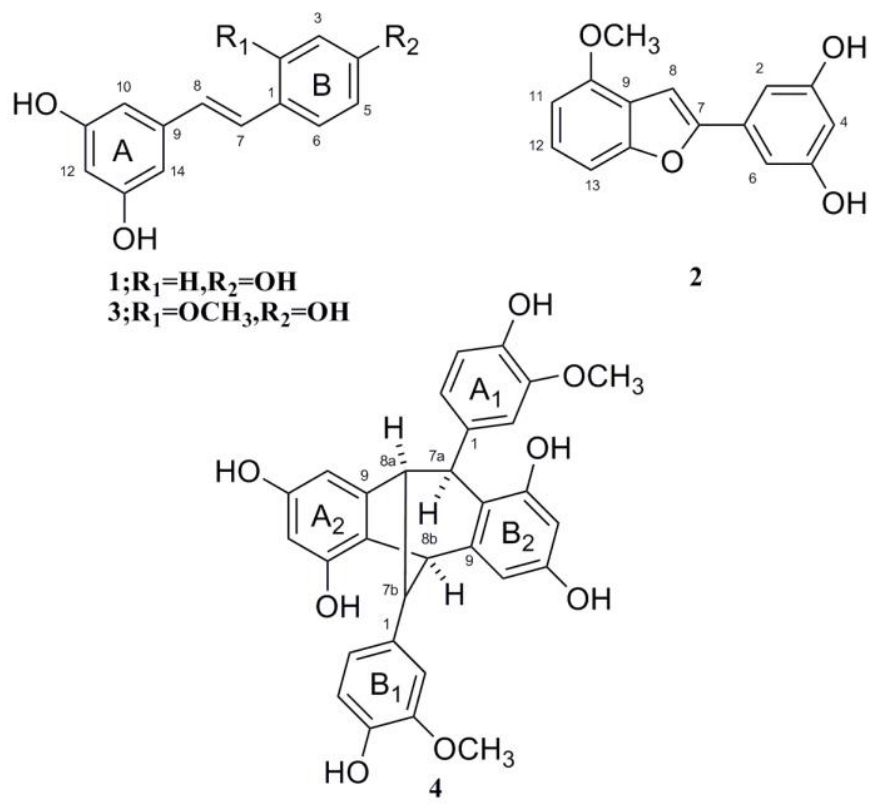

Figure 1. Structure of compound $1-4$ 


\section{Conclusion}

Four known stilbenoids were successfully isolated and characterized from the methanol extract of the lianas of Gnetum cuspidatum Blume. These stilbenoids compounds include resveratrol (1), gnetucleistol C (2), gnetucleistol D (3) and gnemonol M (4). As previous study found that oligostilbenoids from Gnetum displayed diverse pharmacological properties, further detailed on its phytochemical investigation is worth to be explored.

\section{References}

1. Medicinal Herb Index in Indonesia. (1995). PT. EISAI Indonesia, Second Edition.

2. Shimizu, K., Kondo, R. and Sakai. K. (2000). Inhibition of tyrosinase by flavonoids, stilbenes and related 4substituted resorcin. Planta Medica, 66: 11-15.

3. Lojanapiwatna, V., Mahaeja, J. and P. Wiriyachitra. (1982). Isolation of (E)- 3 ,4, 5-trihydroxy-3'methoxystilbene from Gnetum cuspidatum B1. Journal of the Science Society of Thailand, 8(1): 59 - 63.

4. Shimokawa, Y., Hirasawa, Y., Kaneda, T., Hamid, A., Hadi, A. and H. Morita. (2012). Cuspidans A and B, Two New Stilbenoids from the Bark of Gnetum cuspidatum. Chemical and Pharmaceutical Bulletin, 60(6): 790 $-792$.

5. Huang, K. S. and Lin, M. (1999). Oligostilbenes from the Roots of Vitis amurensis. Journal of Asian Natural Products Research, 2: $21-28$.

6. Yao, C. S., Lin, M., Liu, X. and Wang, Y. H. (2005). Stilbene derivatives from Gnetum cleistostachyum. Journal of Asian Natural Products Research, 7: 131 - 137.

7. Yao, C. S., Lin, M., Liu, X. and Wang, Y. H. (2003). Stilbene from Gnetum cleistostachyum. Acta Chimica Sinica, 61 (8): 1331 - 1334.

8. Ilya, I., Ali, Z., Tanaka, T., Iinuma, M., Furusawa, M., Nakaya, K., Murata, J., Darnaedi, D., Matsuura, N. and Ubukata, M. (2003). Stilbene derivatives from Gnetum gnemon Linn. Phytochemistry, 62: 601 - 606. 